\title{
Associative Analysis Data Mining Pattern Against Traffic Accidents Using Apriori Algorithm
}

\author{
Ruswati $^{1}$, Acep Irham Gufroni ${ }^{2}$ Rianto $^{3}$ \\ ${ }^{1,2,3}$ Informatics Departement, Faculty of Engineering, Universitas Siliwangi, Indonesia \\ Email: 'yess.ruswati@gmail.com, ${ }^{2}$ acep@ @unsil.ac.id, ${ }^{3}$ rianto@ unsil.ac.id
}

\begin{abstract}
Traffic accidents are one of the causes of high mortality in the community. Based on information from the World Health Organization (WHO) the number of accident victims in each year amounts to $1,300,000$ fatalities, this is caused by traffic accidents that exist throughout the world. The police recorded data on accidents that occurred in several regions of East Priangan namely Ciamis and Tasikmalaya Regencies for the 2016-2017 period reaching an accident rate of \pm 1500 . The analysis that can be done to reduce the intensity of the occurrence of these events is to use data mining processing techniques. The right method is used by looking at the condition of the data obtained, namely the Association Rules method with the calculation of the Apriori Algorithm. This method will look for patterns of data relations that are formed from combinations of an itemset, so that knowledge will appear from large datasets. The pattern of the relationship sought is the linkages of itemset variables involved in the accident by involving 4 variables that describe the identity of the perpetrators, namely gender, age, profession and level of education and 22 attributes of the dataset. The minimum limit of support, confidence and lift ratio values used in the Apriori Algorithm calculation rules are $15 \%, 70 \%$ and 1.1 . This value is used to get many rules that have a high level of occurrence accuracy. The results of the combination pattern calculation were 3 times iterations on each number of data in each region, the pattern of associations found in the Tasikmalaya region were the relation of the professional variables and the age of the perpetrator with the attribute of the Student profession dataset and the boundary group ages 16 to 30 years, while for the pattern associations found in the area of Ciamis Regency, namely the relation between age and education level with the attribute dataset of the 16 to 30 year age group and high school education level. The accuracy of the value obtained is calculated manually and uses one of the data mining applications as a comparison of value accuracy, namely Tanagra 1.4 .
\end{abstract}

Keywords: Apriori Algorithm, Association Rules, Data Mining, Traffic Accidents

\section{INTRODUCTION}

Traffic accidents have become a social problem that is considered 'normal' for Indonesian people because the intensity of the events is getting higher. Statistical data shows that the number of traffic accidents nationally continues to increase every year. Traffic accidents in 2014 recorded 95,906 accident cases, then in 2015 there were 98,970 accident cases and in 2016 it increased to 105,374 accident cases. The number of traffic accidents in 2017 has decreased, the National Police noted that the number of accidents decreased by $6 \%$ from the previous year to 98,419 accidents. 
The area of Ciamis and Tasikmalaya Districts has become the attention of the police regarding traffic accidents, the police have recorded around 1500 cases of traffic accidents that occurred during the $2016-2017$ period. So, a strategy is needed to find patterns of relationships between data to reduce the occurrence of accidents [1].

Finding knowledge from large amounts of data can use one of the data processing technologies, namely data mining techniques [2]. Association Rules is one of the data mining methods used to find relation patterns between data by determining association rules from data [3]. The Association Rules are also called Market Basketball Analysis because at the beginning they found the concept related to the items in the shopping basket, the concept directly shows the behavior patterns of consumers when shopping $[4,5]$.

Method Association Rules has a number of algorithm choices including the type of data mining association rules, one of the right algorithms with the aim of the research being done is using the Apriori Algorithm [6, 7]. The results that will be obtained from the analysis process are the finding of a pattern of relations between accident data in the Tasikmalaya and Ciamis districts by using associative data mining rules [8].

\section{METHODS}

\subsection{SEMMA Stage}

The data mining preparation process uses SEMMA, this stage is often used in solving data mining problems, the steps that will be taken to produce a knowledge from the data that has been obtained are as follows [9]:

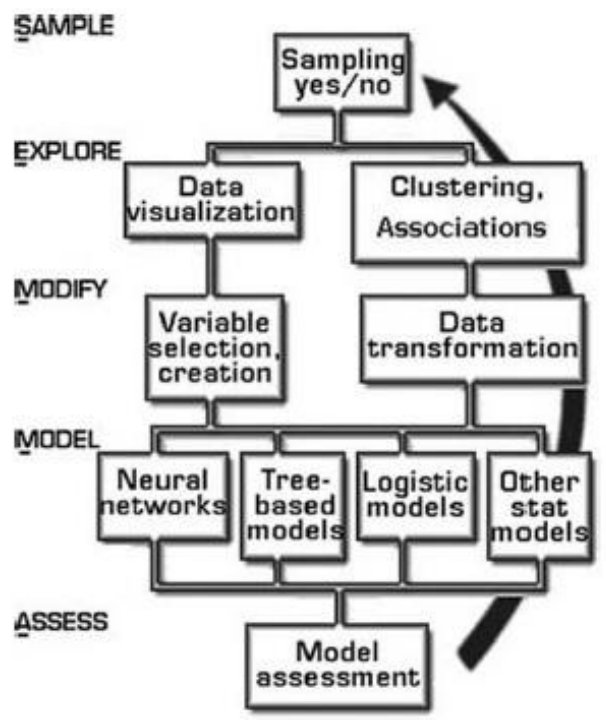

Figure 1. SEMMA diagram [10] 
The stages that are passed are as follows:

1) Sample

Collection of data that will become the main data mining processing material, the completeness of the data in each item that is also considered at this stage.

2) Explore

The stage of looking for data patterns or also called the clustering process is the process of grouping a number of data/objects into groups of data so that the group contains similar data, this stage is called the pro processing stage in the KDD series.

3) Modify

Create and change variables, or eliminate unnecessary variables to focus on the process of selecting models and mining processes.

4) Model

Choose and apply modeling techniques that are appropriate to the conditions of the data obtained in order to obtain optimal results.

5) Assess

Assess data by evaluating the usefulness and discovery functions of the data mining process that has been obtained.

The diagramming process is carried out to process the initial data obtained until the evaluation of the final results. The amount of initial data entered at the Sample stage is as much as 1503 data on accident cases. Then in the Explore stage, the data were grouped based on the area of each Polres, the data group was divided into 2 regions [10] of Tasikmalaya with a total of 795 data and the area of Ciamis Regency as many as 565 data [11]. After arriving at the Modify stage, the amount of data becomes 1360 accident data with the variable description of the involved actors, namely gender (male and female), age-grouped into 5 age limits, namely: $10 \leq$ age $\leq 15,16 \leq$ age $\leq 30,31 \leq$ ages $\leq 40,41 \leq$ ages $\leq 50$, and age $>50$, professions are grouped into 11 profession actors, namely: PNS, TNI, Police, Employees, Students, College Students, Drivers, Traders, Farmers, Laborers and Entrepreneur, and levels education (elementary, junior high, high school, college). The number of attributes involved is 22 attributes [08].

The determination of the data mining calculation process model is the association rule model using the Apriori algorithm to get the relationships between available data to see the involvement of variables involved in the accident in each region, namely Tasikmalaya and Ciamis Regency. The model is chosen because it is in accordance with the objectives of the research conducted. The final stage of SEMMA is to assess the usefulness of the conclusions of the data that has been obtained.

\subsection{Association Rules with Apriori Algorithms}

The Apriori algorithm includes the types of association rules in data mining. Association Rules are data mining techniques to find association rules between a combination of items [6]. Here are the stages of the Apriori Algorithm process in association rules shown in Figure 2. 


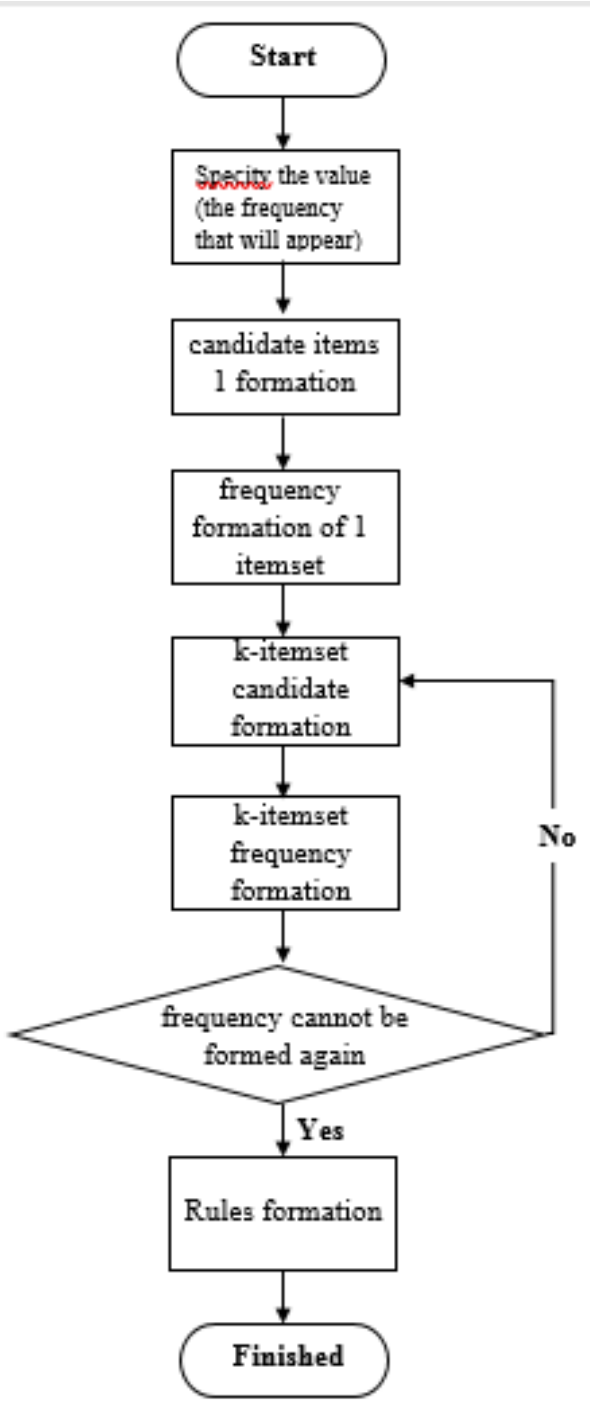

Figure 2. Flowchart apriori algorithms

There are several stages in the process of calculating association rules using the Apriori algorithm, including the following:

1) Formation of Itemset Candidates

Candidate itemset is itemsets that will be calculated with the support value using the formula Support. If the value can be more or equal to the minimum support value, the itemset includes the itemset frequency, but if the value can be less than the minimum support value, the itemset will not enter the next calculation process.

2) Frequency of Itemset 
Itemset frequency is a collection of itemset from $\mathrm{k}$-iterations that have more or equal support values with the specified minimum support.

3) Calculation of Confidence Value

The confidence value of association rules is a measure of the accuracy of a rule or the strong relationship between items in the rules of association A and B.

4) Calculation of Lift Ratio Value

Lift ratio is done to calculate the strength of random event rules that occur in each combination.

The association rule calculation method consists of 3 basic calculations, namely determining the support value, confidence and lift ratio [12]. The minimum value used as the minimum support limit is 0.15 , the minimum confidence limit is $70 \%$, and the lift ratio is 1.1 [12]. The formula for each calculation is [6]:

a. Support

Support value of an item is obtained by the formula:

Support $(A)=\frac{\text { the number of transactions containing } A}{\text { total transaction }} \times 100$

The support value of a combination of 2 items, obtained from the formula:

Support $(\mathrm{A} \cap \mathrm{B})=\frac{\text { the number of transactions containing } A \text { and } B}{\text { total transaction }} \times 100$

etc.

b. Confidence

The confidence value of the $A \rightarrow B$ rule is obtained from the formula:

Confidence $=\mathrm{P}(\mathrm{A} \mid \mathrm{B})=\frac{\text { the number of transactions containing } A \text { and } B}{\text { number of transaction containing } A} \times 100$

c. Lift Ratio

Before calculating the lift ratio, the expected confidence value is obtained, obtained from the formula:

Expected confidence $=\frac{\text { the number of events containing } B}{\text { total events }}$

The results of the calculation of the expected confidence value will be used as a comparison value with the confidence value that has been calculated, obtained from the formula:

Lift ratio $=\frac{\text { confidence }}{\text { expected confidence }}$

\section{RESULT AND DISCUSSION}

\subsection{Association Rules using Apriori Algorithm}

1) Formation of Candidates 1 Itemset

Candidate 1 itemset in the Tasikmalaya area data produces 22 items and items that produce more or equal support values with the specified minimum support that is 8 items.

Candidate 1 itemset in the data area of Ciamis Regency produces 22 items and items that produce more or equal support values with the specified minimum support of 10 items. 
2) The frequency of 1 Itemset

The results table for itemset selection that has a support value meets the minimum limit. The results are shown in Table 1 and Table 2.

\begin{tabular}{clcc}
\multicolumn{3}{l}{ Table } & \multicolumn{3}{c}{ The Frequency of 1} & \multicolumn{3}{c}{ itemsets tasikmalaya region data } \\
\hline No. & \multicolumn{1}{c}{ Item Name } & Support & Support $(\%)$ \\
\hline 1 & Male & 767 & $96,47 \%$ \\
2 & $16 \leq$ age $\leq 30$ & 415 & $52,20 \%$ \\
3 & $41 \leq$ age $\leq 50$ & 125 & $15,72 \%$ \\
4 & Employee & 159 & $20 \%$ \\
5 & Student & 169 & $21,25 \%$ \\
6 & Entrepreneur & 251 & $31,57 \%$ \\
7 & Middle school & 221 & $27,79 \%$ \\
8 & High school & 418 & $52,57 \%$ \\
\hline
\end{tabular}

Table 2. The Frequency of 1 itemsets data ciamis regency

\begin{tabular}{clcc}
\hline No. & \multicolumn{1}{c}{ Item Name } & Support & Support $(\%)$ \\
\hline 1 & Male & 545 & $96,46 \%$ \\
2 & $16 \leq$ age $\leq 30$ & 240 & $42,47 \%$ \\
3 & $31 \leq$ age $\leq 40$ & 91 & $16,10 \%$ \\
4 & $41 \leq$ age $\leq 50$ & 97 & $17,16 \%$ \\
5 & age $>50$ & 93 & $16,46 \%$ \\
6 & Employee & 237 & $41,94 \%$ \\
7 & Student & 108 & $19,11 \%$ \\
8 & Elementary school & 88 & $15,57 \%$ \\
9 & Middle school & 157 & $27,78 \%$ \\
10 & High school & 293 & $51,85 \%$ \\
\hline
\end{tabular}

3) Formation of Candidate 2 Itemset

Candidates 2 itemset involve a combination of 2 related items. Possible relationships have the value of each combination that occurs namely gender $\wedge$ age, gender $\wedge$ profession, gender $\wedge$ education, age $\wedge$ profession, age $\wedge$ education, professional $\wedge$ education.

The number of combinations generated from Tasikmalaya area data is 159 combinations and those included in the high-frequency category are 11 item set. The number of combinations generated from the Ciamis Regency data area is 159 combinations and those included in the high-frequency category are 13 itemsets.

4) The frequency of 2 Itemset

The results table for itemset selection that has a support value meets the minimum limit. The results are shown Table 3 and Table 4. 
Table 3. The frequency of 2 itemsets tasikmalaya region data

\begin{tabular}{clcc}
\hline No. & \multicolumn{1}{c}{ Item Name } & Support & $\begin{array}{c}\text { Support } \\
(\%)\end{array}$ \\
\hline 1 & Male, $16 \leq$ age $\leq 30$ & 403 & $50,69 \%$ \\
2 & Male, 41 $\leq$ age $\leq 50$ & 120 & $15,09 \%$ \\
3 & Male, employee & 157 & $19,74 \%$ \\
4 & Male, student & 164 & $20,62 \%$ \\
5 & Male, entrepreneur & 231 & $29,05 \%$ \\
6 & Male, middle school & 214 & $26,91 \%$ \\
7 & Male, high school & 400 & $50,31 \%$ \\
8 & $16 \leq$ age $\leq 30$, student & 121 & $15,22 \%$ \\
9 & $16 \leq$ age $\leq 30$, entrepreneur & 121 & $15,22 \%$ \\
10 & $16 \leq$ age $\leq 30$, high school & 289 & $36,35 \%$ \\
11 & Entrepreneur, high school & 128 & $16,10 \%$ \\
\hline
\end{tabular}

Tabel 4. Frequency of 2 itemsets data ciamis regency

\begin{tabular}{clcc}
\hline No. & \multicolumn{1}{c}{ Item Name } & Support & $\begin{array}{c}\text { Support } \\
(\%)\end{array}$ \\
\hline 1 & Male, $16 \leq$ age $\leq 30$ & 229 & $40,53 \%$ \\
2 & Male, $31 \leq$ age $\leq 40$ & 88 & $15,57 \%$ \\
3 & Male, $41 \leq$ age $\leq 50$ & 95 & $16,81 \%$ \\
4 & Male, age $>50$ & 92 & $16,28 \%$ \\
5 & Male, employee & 226 & $40,00 \%$ \\
6 & Male, student & 105 & $18,58 \%$ \\
7 & Male, elementary school & 87 & $15,39 \%$ \\
8 & Male, middle school & 154 & $27,25 \%$ \\
9 & Male, high school & 279 & $49,38 \%$ \\
10 & $16 \leq$ age $\leq 30$, employee & 97 & $17,16 \%$ \\
11 & $16 \leq$ age $\leq 30$, student & 121 & $15,22 \%$ \\
12 & $16 \leq$ age $\leq 30$, high school & 168 & $29,73 \%$ \\
13 & The employee, high school & 140 & $24,77 \%$ \\
\hline
\end{tabular}

5) Formation of Candidates 3 Itemset

Candidate 3 itemset involves a combination of 3 item set. Possible relationships have the value of each combination that occurs, including gender $\wedge$ age $\wedge$ profession, gender $\wedge$ age $\wedge$ education, and gender combination $\wedge$ profession $\wedge$ education.

The number of combinations generated from Tasikmalaya region data is 190 combinations and those included in the high-frequency category are 1 item set. The number of combinations generated from the Ciamis area data is 159 combinations and those included in the high-frequency category are 3 item set.

6) The frequency of 3 Itemset

The results table for itemset selection that has a support value meets the minimum limit. The results are shown in Table 5 and Table 6. 
Table 5. The frequency of 3 Itemsets Tasikmalaya Region Data

\begin{tabular}{cccc}
\hline No. & Item Name & Support & $\begin{array}{c}\text { Support } \\
(\%)\end{array}$ \\
\hline 1 & Male, $16 \leq$ age $\leq 30$, high school & 281 & $35,34 \%$ \\
\hline
\end{tabular}

Table 6. The frequency of 3 itemsets data ciamis regency

\begin{tabular}{cccc}
\hline No. & Item Name & Support & $\begin{array}{c}\text { Support } \\
(\%)\end{array}$ \\
\hline 1 & $16 \leq$ age $\leq 30$, high school, male & 158 & $27,96 \%$ \\
2 & The employee, high school, male & 130 & $23 \%$ \\
3 & Employee $16 \leq$ age $\leq 30$, male & 91 & $16,10 \%$ \\
\hline
\end{tabular}

\section{7) Calculation of Confidence Value}

The frequency value obtained from the above three iterations produces several support values that exceed or equal the minimum support value, to calculate the strength of the combination appearance and the strength of the rules obtained, the confidence and lift ratio will be calculated at this stage. At this stage, the iterations included in the calculation of confidence are the second and third iterations which are included in the frequent itemset category. The confidence values are shown in Table 7 and Table 8.

Table 7. Confidence value tasikmalaya region data

\begin{tabular}{clcc}
\hline No. & \multicolumn{1}{c}{ Item Name } & Confidence & $\begin{array}{c}\text { Confidence } \\
(\%)\end{array}$ \\
\hline 1 & $16 \leq$ age $\leq 30$, high school & 291 & $70,12 \%$ \\
2 & Male, high school, $16 \leq$ age $\leq 30$ & 281 & $70,25 \%$ \\
3 & Student, $16 \leq$ age $\leq 30$ & 121 & $71,59 \%$ \\
\hline
\end{tabular}

Table 8. Confidence value ciamis data regency

\begin{tabular}{cccc}
\hline No. & Item Name & Confidence & Confidence $(\%)$ \\
\hline 1 & $16 \leq$ age $\leq 30$, high school & 168 & $70,00 \%$ \\
\hline
\end{tabular}

Itemset which has a confidence value of more than the limit or equal to $70 \%$ then the lift itemset can be calculated by the lift ratio to measure whether or not the rules obtained in the combination have been obtained. The results of the calculation of the lift ratio can be seen in Table 9 and Table 10.

Table 9. Lift ratio value tasikmalaya region data

\begin{tabular}{clcc}
\hline No. & \multicolumn{1}{c}{ Item Name } & Confidence & Lift Ratio \\
\hline 1 & $16 \leq$ age $\leq 30$, high school & $70,12 \%$ & 1,3338 \\
2 & Malei, high school, $16 \leq$ age $\leq 30$ & $70,25 \%$ & 1,3457 \\
3 & Student, $16 \leq$ age $\leq 30$ & $71,59 \%$ & 1,3714 \\
\hline
\end{tabular}


Table 10. Lift ratio value ciamis data regency

\begin{tabular}{cccc}
\hline No. & Item Name & Confidence & Lift Ratio \\
\hline 1 & $16 \leq$ age $\leq 30$, high school & $70,00 \%$ & 1,3500 \\
\hline
\end{tabular}

The above itemset which has a value of confidence and lifts ratio that exceeds the minimum specified level. These rules can be said as rules that have a strong tendency to relate to each other the variable of actors at the time the accident occurred in different areas.

\subsection{Implementation of Association Rules}

The test is done by using one of the data mining calculation software, Tanagra 1.4, to see if the manual calculations calculated before having the same rules results as those produced by data mining processing software. The steps taken in the Tanagra 1.4 software are as follows:

1) Select the excel file in the form of data tabulations in the Tasikmalaya and Ciamis districts alternately. Data tabulation can be seen in Figure 3.

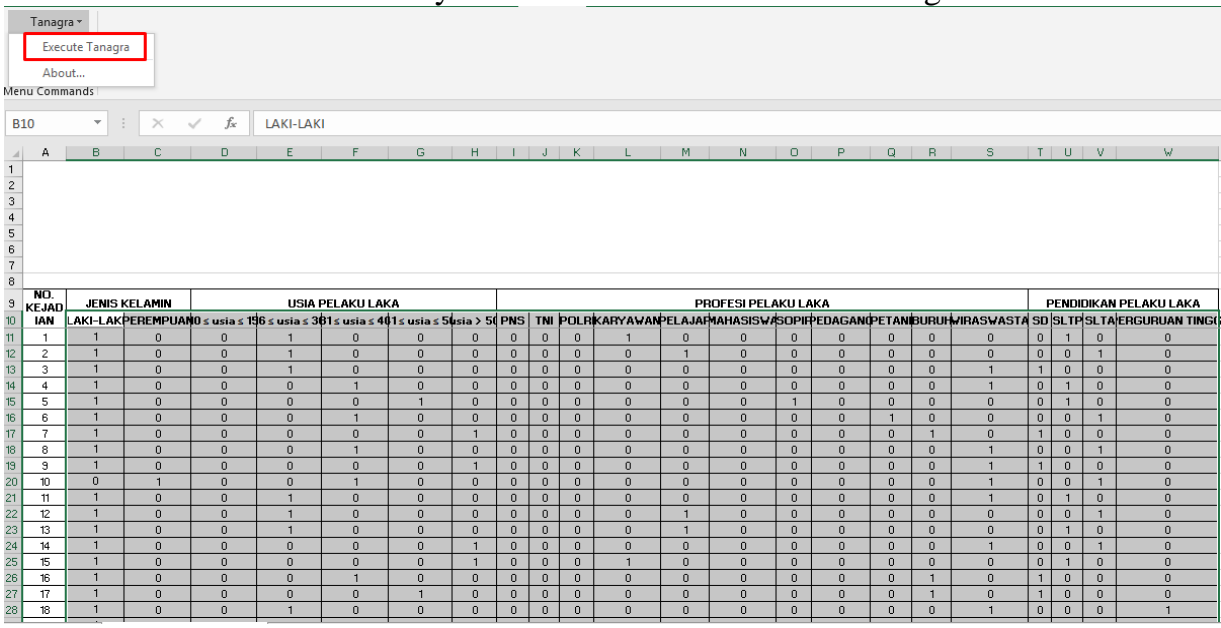

Figure 3. Data tabulation

Data tabulation values for both regions are filled with binary values 1 and 0 . The number 1 means that an item is involved in itemset combinations, while number 0 does not involve itemset combinations.

2) Then select attributes which will be used in association rules. The Define Attribute Statuses can be seen in Figure 4. 


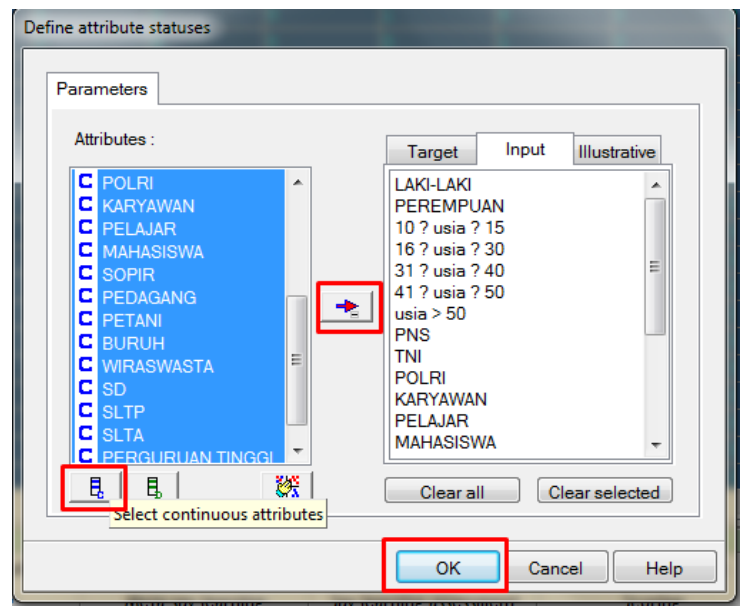

Figure 4. Define attribute statuses

There are 22 attributes used for the calculation process of support and confidence values. Selecting attributes that will be used in the itemset combination process at a later stage. The description of the letter $\mathrm{C}$ on the side of the attribute name indicates that the attribute contains numbers instead of letters.

3) The Process Association Rules in the Tanagra application are found on the menus in the bottom tab, namely the Association. So that the itemset frequency value is obtained, the selected menu is frequent itemsets. The Frequent Itemsets can be seen Figure 5.

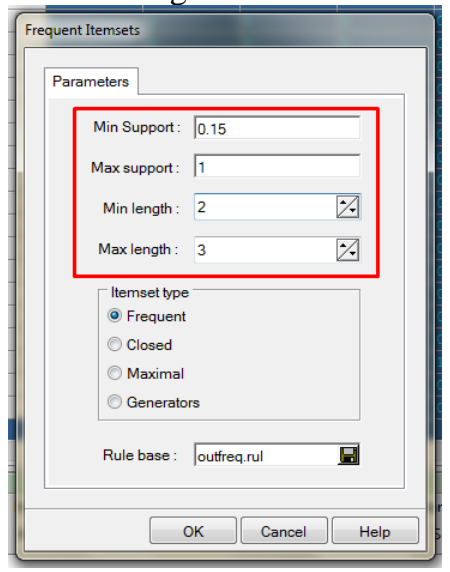

Figure 5. Frequent itemsets

The value entered is in accordance with the minimum support limit used, which is 0.15 with a maximum support of 1 or $100 \%$. The minimum length 
is inputted with a value of 2 and the maximum length enters a value of 3 so that the combination involves 2 to 3 items.

4) Itemset obtained from inputting the minimum support value is shown in Figure 6.

\begin{tabular}{|c|c|c|}
\hline \multicolumn{3}{|c|}{ ITEMSETS [\#16 itemsets loaded] } \\
\hline $\mathrm{N}^{*}$ & Description & Support \\
\hline 1 & SD Л LAKI-LAKI & 14.2 \\
\hline 2 & 41_?_usia_?_50 N LAKKI-LAKI & 15.1 \\
\hline 3 & KARYAWAN $\triangle$ LAKI-LAKI & 19.7 \\
\hline 4 & PELAJAR 八 16_?_usia_?_30 & 15.2 \\
\hline 5 & PELAJARR 八 16_?_usia_?_30 ^ LAKI-LAKI & 14.8 \\
\hline 6 & PELAJAR N LAKI-LAKI & 20.6 \\
\hline 7 & SLTP ^LAKI-LAKI & 27.0 \\
\hline 8 & WIRASWASTA Л 16_?_usia_?_30 & 15.2 \\
\hline 9 & WIRASWASTA ^ 16_?_usia_?_30 ^ LAKI-LAKI & 14.2 \\
\hline 10 & WIRASWASTA Л SLTA & 16.0 \\
\hline 11 & WIRASWASTA A SLTA Л LAKI-LAKI & 14.3 \\
\hline 12 & WIRASWASTA A LAKI-LAKI & 29.2 \\
\hline 13 & 16_?_usia_?_30 / SLTA & 36.6 \\
\hline 14 & 16_?_usia_?_30 ^ SLTA ^ LAKI-LAKI & 35.3 \\
\hline 15 & 16_?_usia_?_30 ^ LAKI-LAKI & 50.7 \\
\hline 16 & SLTA ^ LAKI-LAKI & 50.3 \\
\hline
\end{tabular}

Figure 6. Frequent itemset data in tasikmalaya region

There are 16 itemsets that have a support value exceeding the specified minimum limit, itemset combination starting from 2 to 3 combinations. Te Frequent Itemset data of Ciamis Regency Region shown in Figure 7.

\begin{tabular}{|c|c|c|}
\hline & & \\
\hline$\triangle$ & Description & Support \\
\hline 1 & SD Л LAKKI-LAKI & 15.2 \\
\hline 2 & 31_?_usia_?_40 Л LAKKI-LAKI & 15.6 \\
\hline 3 & usia_>_50 ^ LAKI-LAKI & 16.3 \\
\hline 4 & 41_?_usia_?_50 Л LAKKI-LAKKI & 16.6 \\
\hline 5 & PELAJJAR 八 LAKI-LAKI & 18.4 \\
\hline 6 & SLTP $\wedge$ LAKI-LAKI & 27.3 \\
\hline 7 & KARYAWAN $\wedge$ 16_?_usia_?_30 & 17.2 \\
\hline 8 & KARYAW/AN $\wedge$ 16_?_usia_?_30 ^ LAKI-LAKI & 16.1 \\
\hline 9 & KARYAWAN $\triangle$ SLTA & 24.8 \\
\hline 10 & KARYAWAN $\wedge$ SLTA $\curvearrowright$ LAKI-LAKI & 23.0 \\
\hline 11 & KARYYWAN A LAKI-LAKI & 39.8 \\
\hline 12 & 16_?_usia_?_30 $\triangle \mathrm{SLTA}$ & 29.7 \\
\hline 13 & 16_?_usia_?_30 ^ SLTA $\wedge$ LAKI-LAKI & 28.0 \\
\hline 14 & 16_?_usia_?_30 N LAKKI-LAKKI & 40.4 \\
\hline 15 & SLTA Л LAKI-LAKI & 49.2 \\
\hline
\end{tabular}

Figure 7. Frequent itemset data of ciamis regency region

Has the same number of itemset as data in the Tasikmalaya region, there are 15 itemsets that have a support value exceeding the specified minimum limit, itemset combination starting from 2 to 3 combinations.

5) Still, on the same menu, namely the Association to get the confidence and rules values, the Apriori menu option and enter a confidence limit value 
of $70 \%$ and a lift ratio of 1.1 . Association rule parameter is shown in Figure 8 .

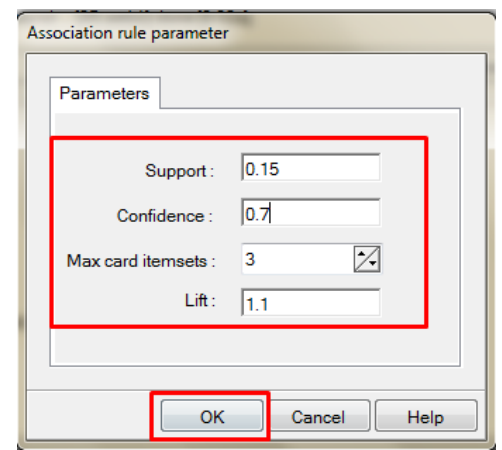

Figure 8. Association rule parameter

6) Rules obtained from calculations using the Tanagra 1.4 application for data in each region shown in Figure 9.

\begin{tabular}{|c|c|c|c|c|c|}
\hline \multicolumn{6}{|c|}{ Number of rules : 3} \\
\hline $\mathrm{N}^{*}$ & Antecedent & Consequent & Lift & Support (\%) & Confidence (\%) \\
\hline 1 & "PELANAR=true" & -16 ? usia ? 30=true" & 1.37157 & 15.220 & 71.598 \\
\hline 2 & "LAKI-LAKI=true" - "SLTA=true" & "16 ? usia ? 30=true" & 1.34575 & 35.346 & 70.250 \\
\hline 3 & -16 ? usia ? 30=true" & "sLTA=true" & 1.33363 & 36.604 & 70.120 \\
\hline
\end{tabular}

Figure 9. Tasikmalaya region data rules

Produces 3 rules which each rule produces an average value of $70.00 \%$. Ciamis Regency Area Data Rules is shown in Figure 10.

\section{RULES}

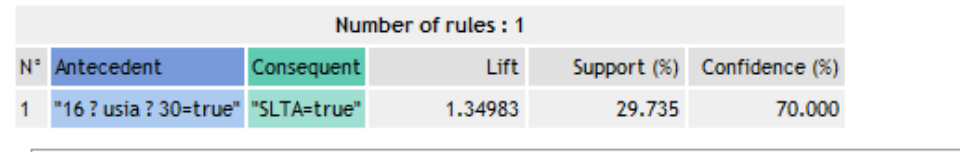

Figure 10. Ciamis regency area data rules

Get 1 rule with a confidence value of $70.00 \%$. The combination that can be obtained is age $\wedge$ education $\rightarrow 16 \leq$ age $\leq 30 \wedge$ high school.

\subsection{Comparison of the Calculation Results of the Apriori Algorithm Rule Using Tanagra}

Comparison of itemset from each calculation in the data of Tasikmalaya and Ciamis Districts can be seen in Table 11. 
Table 11. Comparison of rules results

\begin{tabular}{|c|c|c|c|c|c|c|}
\hline \multirow[b]{2}{*}{ No. } & \multirow[b]{2}{*}{$\begin{array}{l}\text { Name of } \\
\text { Region }\end{array}$} & \multirow[b]{2}{*}{ Item Name } & \multicolumn{2}{|c|}{ Manual Calculation } & \multicolumn{2}{|c|}{ Tanagra Software } \\
\hline & & & Confidence & $\begin{array}{c}\text { Lift } \\
\text { Ratio }\end{array}$ & Confidence & $\begin{array}{c}\text { Lift } \\
\text { Ratio }\end{array}$ \\
\hline \multirow{3}{*}{1} & & $\begin{array}{l}16 \leq \text { age } \leq 30, \text { high } \\
\text { school }\end{array}$ & $70,12 \%$ & 1,3338 & $70,120 \%$ & 1,33363 \\
\hline & Tasikmalaya & $\begin{array}{l}\text { Male, high school, } \\
16 \leq \text { age } \leq 30\end{array}$ & $70,25 \%$ & 1,3457 & $70,250 \%$ & 1,34575 \\
\hline & & $\begin{array}{l}\text { Student, } 16 \leq \text { age } \leq \\
30\end{array}$ & $71,59 \%$ & 1,3714 & $71,598 \%$ & 1,37157 \\
\hline 2 & Ciamis & $\begin{array}{l}16 \leq \text { age } \leq 30, \text { high } \\
\text { school }\end{array}$ & $70,00 \%$ & 1,3500 & $70,00 \%$ & 1,34983 \\
\hline
\end{tabular}

The values obtained from the calculation process of support, confidence and lift ratios in each region have the same number of values, but have the provisions in determining rounding numbers behind a different comma, so that the results obtained have a difference or a difference of 0.007 or in the form of a percentage of $0.07 \%$. The difference with the difference in numbers is considered to have the same value.

\section{CONCLUSION}

The conclusion that can be drawn from this research is the Rules that have lift ratio values above 1.1 and confidence more or equal to the minimum confidence can be referred to like rules that have the strongest tendency to relate between variable actors when an accident occurs. In the Tasikmalaya area data, the pattern obtained from the manual calculation process and using the application is the existence of a relationship between the variable professional perpetrators $\cap$ Age $\rightarrow$ "If the Student profession is $16 \leq$ of age $\leq 30$ " with the strong value of the tendency of the rules appear 1.3714. District data of Ciamis regency, the rules of association that can be obtained are the relationship between the variables of Age $\cap$ Last Education $\rightarrow$ "If aged $16 \leq$ age $\leq 30$ then high school education level" with the strong values of the trend rules appear as much as 1.3500 .

\section{REFERENCES}

[1] Aribowo, A. S. (2015). Analisa Asosiatif Data Mining Untuk Mengetahui Pola Kecelakaan Lalu Lintas. Telematika, 8(2), 2-7.

[2] Fauzy, M., \& Asror, I. (2016). Penerapan Metode Association Rule Menggunakan Algoritma Apriori Pada Simulasi Prediksi Hujan Wilayah Kota Bandung. Jurnal Ilmiah Teknologi Informasi Terapan, 2(3).

[3] Utari, P. N., \& Hakim, R. B. (2015). Penerapan Metode Association Rule Menggunakan Algoritma Apriori untuk Analisa Pola Data Kecelakaan Pesawat Dari Tahun 1967-2014 di Indonesia. Prosiding Seminar Nasional Matematika dan Pendidikan Matematika UMS. pp. 753-763.

[4] Suryanto. (2017). Data Mining untuk Klasifikasi dan Klasterisasi Data. Bandung: Informatika.

[5] Sari, E. N. (2013). Analisa Algoritma Apriori Untuk Menentukan Merek Pakaian Yang Paling Diminati Pada Mode Fashion Group Medan. Pelita Informatika: Informasi dan Informatika, 4(3), 35-39. 
[6] Vulandari, R. T. (2017). Konsep Dasar Data Mining, 1st ed. Yogyakarta: Gava Media.

[7] Tampubolon, K., Saragih, H., \& Reza, B. (2013). Implementasi Data Mining Algoritma Apriori pada Sistem Persediaan Alat-Alat Kesehatan. Informasi dan Teknologi Ilmiah (INTI), 1(1), 93-106.

[8] Saragih, R. (2017). Implementasi Apriori Pada Data Kecelakaan Lalu Lintas Dalam Pencarian Relasi Antar Variabel Pelaku. Algoritma: Jurnal Ilmu Komputer Dan Informatika, 1(01), 12-17.

[9] Olson, D. L., \& Delen, D. (2008). Advanced data mining techniques. Springer Science \& Business Media.

[10] Yanto, R., \& Di Kesuma, H. (2017). Pemanfaatan Data Mining Untuk Penempatan Buku Di Perpustakaan Menggunakan Metode Association Rule. Jurnal Teknik Informatika dan Sistem Informasi, 4(1), 1-10.

[11] Setianingsih, D., \& Hakim, R. B. (2015). Penerapan Data Mining dalam Analisis Kejadian Tanah longsor di Indonesia dengan Menggunakan Association Rule Algoritma Apriori. pp. 731-741.

[12] Kuswardani, D., Widyanto, M. R., \& Trihandini, I. (2011). Metode Association Rule Untuk Analisis Citra Ct Organ Pasien Kanker Ovarium. Jurnal Ilmiah Kursor, 6(2), 111-120. 